\title{
THE SPATIAL DISTRIBUTION OF POTHOLES IN UUSIMAA, SOUTHERN FINLAND
}

\author{
TUIJA JANTUNEN
}

\begin{abstract}
JANTUNEN, TUIJA, 1996. The spatial distribution of potholes in Uusimaa, southern Finland. Bull. Geol. Soc. Finland 68, Part 2, 40-45.

It has been assumed, on the basis of the distribution of potholes in the bedrock near eskers, that they were eroded by subglacial meltwaters connected with the formation of eskers. As seen from the spatial distribution of potholes in the county of Uusimaa in southern Finland they occur in narrow zones in a southwest-northeasterly direction, close to the big fault lines in the bedrock. It can therefore be concluded that most of these potholes were formed parallel to the ice margin in crevasses where meltwaters together with stones and boulders eroded potholes into the underlying bedrock. The crevasses may have been formed near the ice margin as a result of earthquakes along fault lines in the bedrock caused by the land uplift during deglaciation.
\end{abstract}

Key words: potholes, spatial distribution, fault zones, genesis, ice sheets, crevasses, Quaternary, Uusimaa Province, Finland.

Tuija Jantunen, Kämnerinkuja 1 B 25, FIN-00750 Helsinki, Finland.

Potholes have for long fascinated people and have locally been held to be sights worth visiting, but their distribution and importance as erosional features of glacial meltwaters have been surprisingly little studied. The probably most extensive investigation of potholes and related formations in Finland was undertaken by Rosberg (1925), who summarised what was known about them at the beginning of the 20th century. 1300 formations were known at that time, of which over 1000 were potholes. The majority of the potholes in Finland (including the pre-Second World War areas of Finland) are in the coastal area of southern Finland and the northern shores of Lake Ladoga. Elsewhere in Finland very few potholes have been found, presumably because they have been covered by sediments from the time of deglaciation. Rosberg (1925), however, produced a detailed list and description of the potholes, but the use of the list is made difficult as no coordinates are given for the sites, which can therefore not be located on the topographical maps. Very few potholes are marked on these maps and a throrough investigation of these glaciofluvial features would require a new detailed survey.

In the present account of the spatial distribution of potholes in Uusimaa in southern 


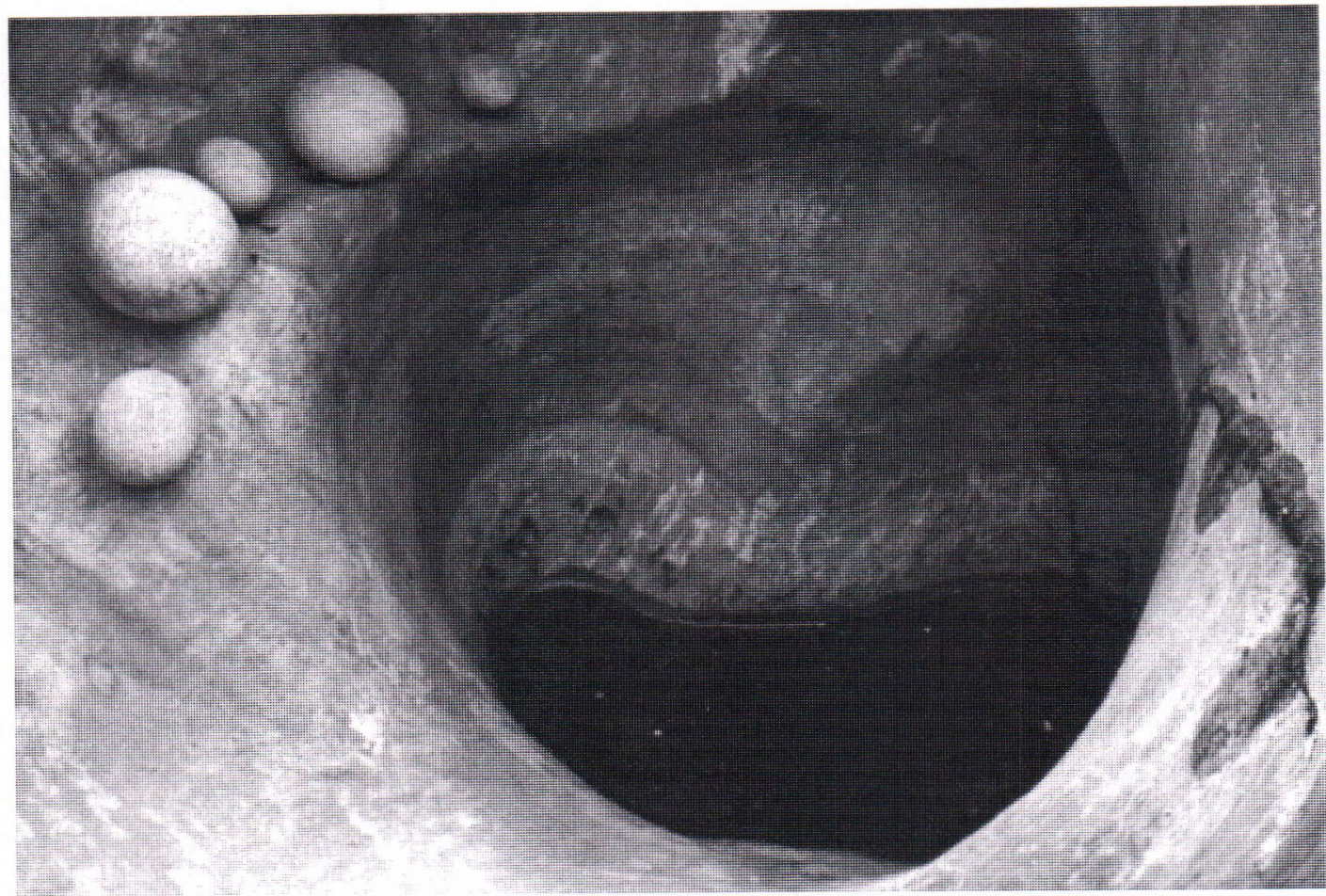

Figure 1. Pothole in Mikkeli, central Finland, with a diameter of about $2 \mathrm{~m}$.

Finland Rosberg's (1925) publication together with topographical maps were used as sources. On the basis of Rosberg's descriptions the positions of as many potholes as possible were determined, in some places with an accuracy of only 1-2 $\mathrm{km}$. In addition a report by the Ministry of Environment (Kananoja and Grönholm, 1993) was used. About 400 potholes were recorded, but for sites with many potholes close to one another only one pair of coordinates was recorded and one dot marked on the map in Fig. 2 , which has 130 dots in all. The potholes often occur in groups or in a line, but also as single features.

It seems indisputable that potholes were formed by meltwaters in moulins, where the scouring was furthered by stones in the glacial ice which together with the water excavated even deep hollows. According to Rosberg (1925) and
Virkkala (1959) potholes are often connected with eskers and are therefore found close to these ridges. This observation has resulted in the conclusion that the potholes follow in a line the direction of the eskers, which, however, is only the case in a few places. The meltwaters that formed the esker going through Mikkeli in central Finland scoured, for instance, a large pothole on the eastern side of the esker (Fig. 1). However, when the potholes are plotted on a map they occur in lines parallel to the ice margin, at right angles to the eskers. The direction of the lines is the same as that for De Geer moraines in the Mäntsälä and Hyvinkää areas (Aartolahti, 1972). Further, the great fault lines in Uusimaa are parallel to these lines near the coast, the potholes occurring southeast of the faults (Fig. 2). The most important of these are the Pikkala-Lahti fault (Jantunen, 1990) and the 


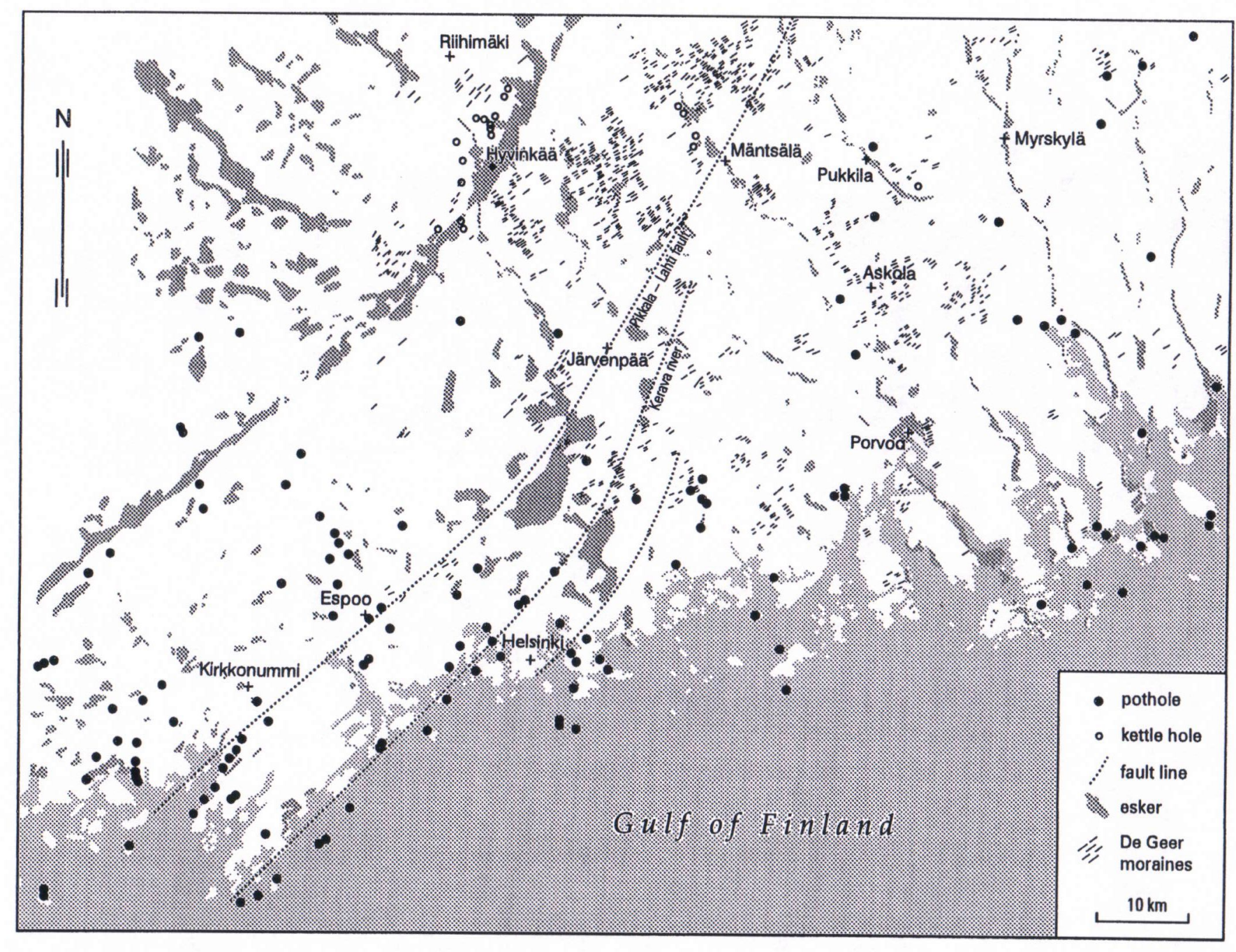

Figure 2. The distribution of potholes in Uusimaa, southern Finland. 
fault, in which the Kerava river flows, southeast of a marginal formation (Hyyppä, 1950).

Whereas the distribution of the potholes can be mapped the time of their formation is more difficult to determine. When assessing the age of potholes the positions of the moulins in which they were formed has to be taken into account. Firstly, as the scouring of potholes requires strong meltwater action it can be assumed that they were formed during the deglaciation. It is, however, more difficult to determine if they originated in front of the ice margin or clearly away from it, in crevasses parallel to the ice margin. The formation of crevasses may have been furthered by earthquakes during the final stages of deglaciation. It is unlikely that the potholes are older than the last glaciation, because they would hardly have survived the erosion of the bedrock by the ice.

Many potholes are filled with glacial drift but this does not prove that they are older than the last glaciation, because a pothole formed in a moulin may have been filled during a readvance of the ice margin or at the time of the final melting of the ice. Many of the potholes described by Rosberg (1925) were filled by drift. Whether they were filled or not also depended on the altitude at which they are situated; those at lower altitudes were presumably more likely to have been filled with sediments than the ones at higher altitudes. The altitudes of the potholes in Uusimaa vary between 0 and $100 \mathrm{~m}$ above sea level.

If the potholes were formed below crevasses comparatively far inside the ice margin they could later have been filled with glaciofluvial sediments (Fig. 3). It is also possible that potholes were filled with till during a readvanve of the ice, or with meltout till during the final decay of the ice. Older crevasses may have closed during this process.

The assumption that potholes were formed in crevasses rather than at the ice margin is also supported by the fact that the crevasses remained in the same place long enough for even large potholes to be formed, as those in Pihlajanmäki

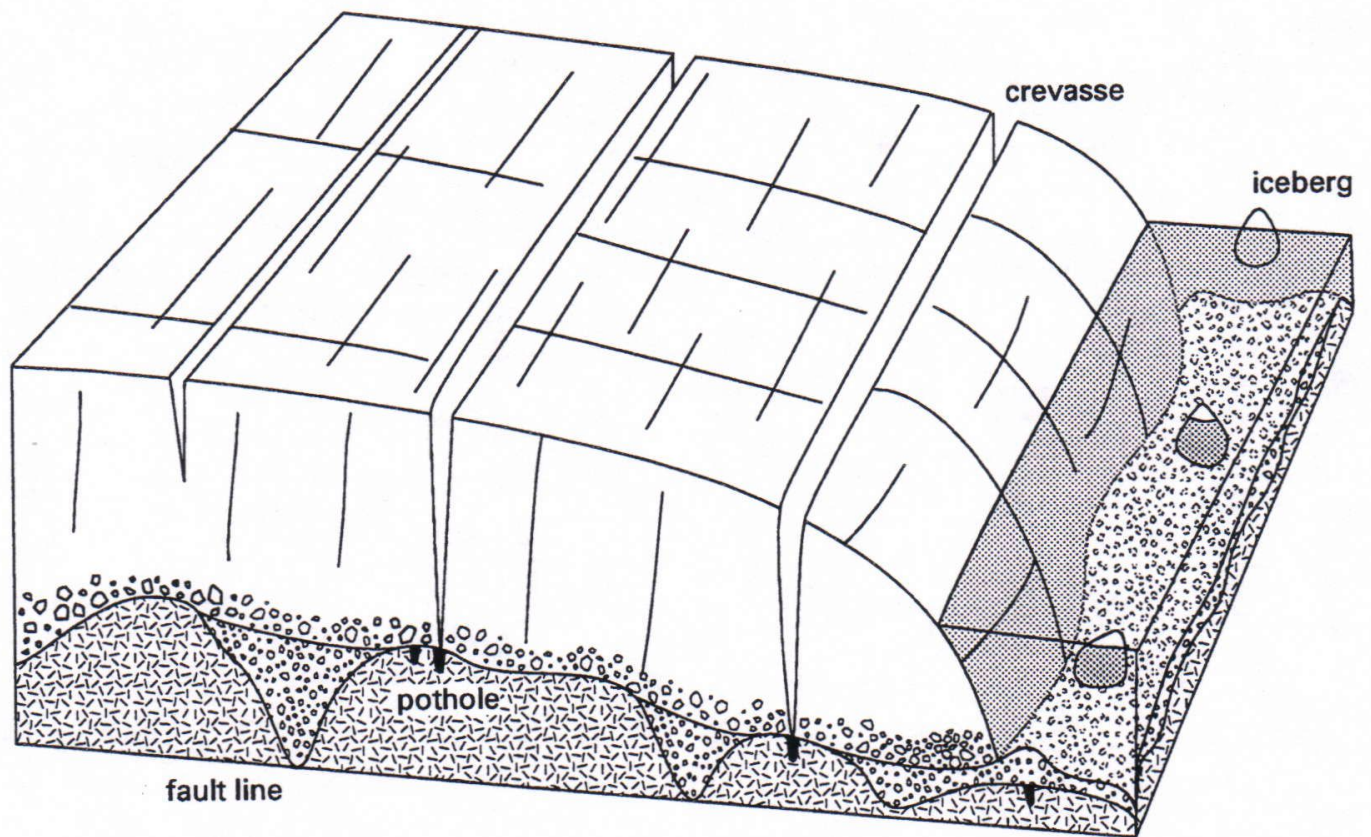

Figure 3. A model of crevasses in the marginal zone of the inland ice and the position of potholes. 
near Helsinki (Hirvas, 1995), whereas the ice margin retreated during deglaciation. The Pihlajanmäki potholes are situated on the southeastern side of the fault line connected with the Kerava river and are part of the long line of potholes along the coast in a southwest-northeasterly direction. On the other hand, potholes, being fairly close together, are also grouped in lines in the direction of eskers. A waterfall in a crevasse can be assumed to have eroded the ice and thus moved in a northwesterly direction, resulting in the formation of new potholes northwest of previously formed potholes, in the same drainage system of a crevasse (Fig. 3).

The map in Fig. 2 also shows kettle holes in glaciofluvial sediments. They are scarce south of the Salpausselkä moraine, because some of them were filled with Baltic sediments when they were submerged during deglaciation (Granö, 1958). The kettle holes are interesting in connection with the potholes because they resemble large potholes but occur in eskers and glaciofluvial marginal formations and are considered to have been formed as dead ice hollows. As the area south of the outer Salpausselkä moraine was covered by tens of metres of water during deglaciation, it is difficult to envisage how blocks of ice could remain under water on the bottom, melt in situ and leave hollows in their place. The blocks of ice would rather have risen to the surface and become floating icebergs.

It is more probable that at least some of the kettle holes south of Salpausselkä were formed by waterfalls near the ice margin during deglaciation than by dead ice. This explanation was found to be the most plausible in the investigation of the sediments of the Vessö esker in Seitlax (Jantunen, 1995), where clays of the Baltic Ice Lake and later stages, up to the Litorina Sea stage, were deposited in a hollow resembling a kettle hole in the middle of the esker. The formation of kettle holes north of the Salpausselkä moraine as dead ice hollows is easy to understand, because there was a very shallow water cover, if any. But in principle waterfalls may even there have excavated hollows into the sediments as there are potholes as well. Especially steep-sided narrow kettle holes with water-worn stones lowermost may have been excavated by meltwaters. The shapes of the blocks of ice from the ice margin were hardly regularly cone-shaped as the kettle holes near the Salpausselkä moraine would suggest.

It may be concluded that most potholes were formed below open crevasses parallel to the ice margin, during deglaciation. There are, in addition, potholes near eskers, indicating that they were formed by meltwater streams transporting and depositing glaciofluvial sediments. From this the question arises whether also kettle holes could have been excavated in the eskers by meltwater scouring in moulins. That some closed depressions in sediments may have been formed in this way has earlier been suggested by Meyer (1973), as mentioned by Ehlers (1996) in his discussion of the formation of kettle holes. 


\section{REFERENCES}

Aartolahti, T. (1972) On deglaciation in southern and western Finland. Fennia 114, 1-84.

Granö, O (1958) The Vessö esker in southern Finland and its economic importance. Fennia 82:1, 1-33.

Ehlers, J. (1996) Quaternary and glacial geology. Wiley, $578 \mathrm{pp}$.

Hirvas, H. (1995) Interview by Esko Pasanen: Pihlajanmäen hiidenkirnut viimeistä jääkautta vanhempia. Helsingin Sanomat 20.10.1995.

Hyyppä, E. (1950) Helsingin ympäristö. Maaperäkartan selitys. Geologinen tutkimuslaitos, Helsin$\mathrm{ki}, 53 \mathrm{pp}$.

Jantunen, T. (1990) Maankohoamisen saranalinjoista Suomen kallioperässä: Tutkimuskohteena Pikkalan-Lahden murroslaakso (Abstract: The hingeline in the uplift in the Finnish bedrock: The Pikkala-
Lahti fault line as study area). Terra 102:3, 158163.

Jantunen, T. (1995) A late Litorina transgression in the district of Porvoo in southern Finland. Annales Academiae Scientiarum Fennicae, Series A, III $158,40 \mathrm{pp}$

Kananoja, T. and Grönholm, S. (1993) Uudenmaan kallioperän suojelu- ja opetuskohteita. Tutkimusraportti 3. Ympäristöministeriö, Alueidenkäytön osasto. $248 \mathrm{pp}$.

Meyer, K-D. (1973) Zur Entstehung der abflusslosen Hohlformen auf der Neuenwalder Geest. Jahrbuch der Männer vom Morgenstern 53, 23-29.

Rosberg, J. E. (1925) Jättegrytor i södra Finland. Fennia 46:1, 104 pp.

Virkkala, K. (1959) Maaperäkartan selitys, lehti 2043 Kerava. Suomen geologinen kartta 1:100 000, 99 pp. 